\title{
Legislative Ambiguity and Ontological Hierarchy in US Sacred Land Law
}

\author{
Adam Dunstan
}

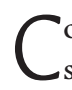

onflicts over Native American sacred landscapes have an unexpectedly broad salience at the present moment. ${ }^{1}$ The Dakota Access Pipeline brought national and international visibility to what is a daily, but invisible, reality for many indigenous nations in the United States and across the world: the despoliation of cultural landscapes under regimes of resource colonialism and environmental racism. The current moment presents an opportunity to discuss the possibilities, as well as the confines, of US policy and law as these relate to indigenous sacred lands ${ }^{2}$ Environmental and cultural policies in the United States, even when ostensibly designed to protect indigenous sacred site practices, often fail to protect those practices in the courtroom, from Standing Rock to the San Francisco Peaks, from Chimney Rock to Snoqualmie Falls. ${ }^{3}$ The reasons for these failures are complex and multifaceted, including most significantly the basic reality of the occupation of indigenous nations' land by settlercolonial regimes favoring resource extraction. The specific delineation of "free exercise of religion" within broader case law on sacred sites is critically important. ${ }^{4}$ In addition, however, the written language of sacred site policies and laws itself poses intrinsic limitations. Milholland, for example, remarks that federal law "imposes values, concepts, and languages of the dominant Western society," 5 and argues that in regard to sacred land protections there is a need to "scrutinize existing law and management practices for incompatible and hegemonic ideologies and languages." 6

This essay is an attempt to engage in such scrutiny. While Milholland analyzes the process of marginalizing Native American ontologies by focusing more heavily on

Adam Dunstan is an assistant professor of anthropology at the University of North Texas. His scholarship centers on environmental policy, activist discourse, and sacred landscapes, including the ongoing desecration of the San Francisco Peaks. His publications include "What Was Damaged? Taking Sacred Ecology into Account in Environmental Impact Assessment" and "Toxic Desecration: Science and the Sacred in Navajo Environmentalism." 
concepts within laws that are incommensurable with Native views and the resultant land management practices, this article focuses on judicial opinions that interpret opaque terms within legislation. I argue that the imposition of hegemonic ideologies within sacred site management occurs in some cases precisely because there are ambiguities in law and policies. ${ }^{7}$ While seemingly neutral and requiring no explanation, these broad terms ultimately must be interpreted within an ontological framework. I contend that this ambiguity in terms lends a disproportionate weight of authority to judicial interpretations of Native American religious practices. Such interpretations often rely upon ontological assumptions directly in contrast to those of indigenous practitioners, establishing hegemonic control over the definition of sacred lands and their threats.

Drawing on examples from efforts to protect a sacred mountain in northern Arizona (the San Francisco Peaks), I highlight how phrases in two vital laws-the American Indian Religious Freedom Act (AIRFA) and the Religious Freedom Restoration Act of 1993 (RFRA) - render them liable to such exclusionary and ethnocentric interpretations when put into practice, even when laws are designed for the explicit purpose of protecting indigenous practices. Hegemonic, Euro-American ontological understandings of the nature of land, and thus the nature of its threats, are often predetermined in the courtroom as more accurate than indigenous views, resulting in a frequent failure to recognize and prevent significant harms to indigenous lifeways. In short, these sacred site laws and policies emerge from, yet simultaneously seem to ignore, the settler-colonial power dynamics and attendant "exclusionary hierarchy of knowing and being," 8 to use Schultz's phrase, within which Native American nations contend for their continued cultural survival vis-à-vis sacred lands, and this limits the potential for providing effective protection for culturally significant landscapes.

In describing these limitations of the law, my perspective is that of an ethnographer who has conducted research for several years on topics concerning Native American sacred landscapes and has witnessed how legal interpretations of significant sacred sites laws can fail to correspond to Native American lived experiences with the sacred and protect them. In approaching this topic, I hasten to add that existing sacred site laws and policies are necessary and important. My intention is not so much to criticize as to critique; to engage in introspection, rather than iconoclasm; and, in the interest of true environmental justice and cultural protections, to provoke consideration of how laws and policies might be better designed and, perhaps even more importantly, interpreted.

\section{The Patchwork of Sacred Site LaW and Policy in the United STATES}

Sacred site policy and law in the United States consists of a patchwork of legislation, executive orders, policy declarations, and other devices of governmentality developed at different times and for different, if overlapping, purposes. Certain instrumentalities lend themselves more effectively to sacred site protection than others, although numerous court cases have shown that in cases involving powerful extraction or 
development interests, or conflicting agency directives, any of these instruments can fail to protect sacred landscapes ${ }^{9}$

The patchwork of sacred site legalities in the United States begins with the First Amendment of the Bill of Rights, and more specifically the free exercise clause, which states that "Congress shall make no law respecting an establishment of religion, or prohibiting the free exercise thereof." 10 In theory this clause protects Native American religious freedoms alongside those of other inhabitants of the United States, yet this has often not been the case, as demonstrated by a lengthy history of outlawing indigenous ceremonies, persecution of traditionalist practitioners, and forced Christianization of Native American children. ${ }^{11}$ Circuit courts and the US Supreme Court have repeatedly emphasized the position that the First Amendment does not mandate protection of sacred sites, even if tribes consider these sites indispensable to their free exercise of religion. ${ }^{12}$ In one of the most infamous sacred site legal cases, Lyng v. Northwest Indian Cemetery Protective Association, Karok, Tolowa, and Yurok plaintiffs specifically litigated a First Amendment argument to prevent the construction of a logging road through a sacred landscape. The Supreme Court, in its majority opinion against the plaintiffs, argued that the logging road did not constitute an abridgement of the free exercise clause of the First Amendment as the federal government had neither coerced Native Americans to act against their religion nor punished them for performing ceremonies. ${ }^{13}$

In addition to the First Amendment, several significant laws and policies arose in the twentieth century which potentially have bearing on the protection of Native American sacred lands and tribes have at various times utilized them for this purpose. In chronological order, some of these include the National Historic Preservation Act (NHPA), ${ }^{14}$ the National Environmental Policy Act (NEPA), ${ }^{15}$ the American Indian Religious Freedom Act (AIRFA), ${ }^{16}$ the Archaeological Resources Protection Act of 1979 (ARPA), 17 Native American Graves Protection and Repatriation Act (NAGPRA), ${ }^{18}$ the Religious Freedom Restoration Act of 1993 (RFRA), 19 and Executive Order 13007 ("Indian Sacred Sites"), ${ }^{20}$ among others ${ }^{21}$ Several of these laws and policies - particularly AIRFA, RFRA, and EO 13007-emerged out of the long history of abuse of Native American religious freedoms, which gained congressional attention throughout the latter half of the twentieth century due to Native American lobbying 22 as well as the recognition that unique aspects of indigenous sacred practices render them particularly vulnerable to activities undertaken and facilitated by the US government.

In many Native American sacred lifeways, land (whether in general or at particular sites) is inextricably connected to a holistic way of life, ${ }^{23}$ including religious practices. ${ }^{24}$ In fact, the peoplehood matrix devised by Holm, Pearson, and Chavis-a classic American Indian studies conceptual model of central elements of distinct peoplesposits place or territory as a fundamental component of indigenous peoplehood, interconnected with language, a ceremonial cycle, and sacred history. ${ }^{25}$ Scholars have named the centrality and sacredness of land within indigenous traditions using a variety of terms, such as "eco-centricity," 26 "primal cosmology," 27 and "nature-centered spirituality," 28 among others. The sacredness of certain culturally significant landscapes 
in particular often leads to friction and conflict with the federal government because the United States forcibly expropriated a large portion of indispensable Native American sacred lands which are presently located within national parks, forests, and other public lands. ${ }^{29}$ Federal lands containing indigenous sacred sites are often managed to further activities which, from the perspective of indigenous peoples, at various times and in various ways may constitute desecration, such as mining, ${ }^{30}$ logging, ${ }^{31}$ and outdoor recreation. ${ }^{32}$ In such a context, conflicts repeatedly arise between governmental land regimes and the essentials of indigenous religious practices. In fact, United States legislation explicitly recognizes (although does not necessarily correct) this fundamental tension. The preamble of AIRFA, for example, declares that "the lack of a clear, comprehensive, and consistent Federal policy has often resulted in an abridgement of religious freedom for traditional American Indians. . . [L]aws and policies often deny American Indians access to sacred sites required in their religions." 33

AIRFA and other laws and policies such as EO 13007 arise from, and are ostensibly designed to ameliorate, this conflict between use of Native sacred sites and federal land management by considering and accommodating Native religious practices. However, ambiguities in the language of these laws and policies opens them up to interpretation, which in the court system of a settler-colonial power often works against tribes seeking legal protection of sacred lands, precisely because such interpretations are rooted in an ontological standpoint very different from that of the indigenous peoples whose lands are threatened. This article will demonstrate some of these ambiguities and their ramifications by analyzing two court cases regarding skiresort development on the San Francisco Peaks in northern Arizona.

\section{AIRFA and Wilson v. Block: Contested Meanings of "Access" and "Use"}

AIRFA emerged in the context of Native American advocacy and an increased recognition by Congress of the frequent infringement of federal laws and policies on indigenous religious practitioners. Such infringements included, for example, laws affecting ceremonial peyote use, eagle feather possession, and ceremonies on public land. 34 The Act commits the United States to "protect and preserve for American Indians their inherent right of freedom to believe, express, and exercise the traditional religions of the American Indian ... including but not limited to access to sites, use and possession of sacred objects, and the freedom to worship through ceremonials and traditional rites." 35

Nonetheless, throughout the 1980s, as tribes attempted to leverage AIRFA in combination with the First Amendment for sacred land protections, the Act was found to contain intrinsic limitations to its effectiveness. The most widely acknowledged of these limitations is its lack of enforceability. On the basis of the Act's language and congressional discussion surrounding its passage, AIRFA has been interpreted to constitute a congressional statement of policy lacking any legal compulsion for sacred site protection or penalty for failure to do so; the common sentiment is that it is "toothless." ${ }^{6}$ For example, while harm to Native American religious practices was explicitly acknowledged by the courts in Lyng v. Northwest Indian Cemetery Protective 
Association, ${ }^{37}$ the Supreme Court's majority opinion holds that AIRFA does not "create a cause of action or any judicially enforceable individual rights." 38 Similarly, in Wilson v. Block, the Supreme Court majority argues that AIRFA required federal agencies to "consider, but not necessarily defer to, Indian religious values." 39 By interpreting AIRFA as a procedural directive to consider sacred sites, rather than a statutory obligation to protect them, the Wilson $v$. Block decision and subsequent cases (particularly Lyng) render the Act largely unenforceable as a means of injunction in cases where federal agencies are committed to a particular land use. ${ }^{40}$

AIRFA's lack of enforceability has been widely recognized. ${ }^{41} \mathrm{I}$, therefore, focus instead on a subtler, but no less significant, dimension of AIRFA which hinders the Act: the politics of defining the pivotal terms of "access" and "use." AIRFA's language expresses the policy ideal of "protecting and preserving ... access to sites [and] use and possession of sacred objects," 42 thus explicitly acknowledging that access to sacred sites is central to Native American religious traditions and is therefore covered by the free exercise clause of the First Amendment. ${ }^{43}$ However, what precisely constitutes "access" to sacred sites and "use" of sacred objects is a critical ambiguity in sacred site jurisprudence, particularly AIRFA.

The disastrously negative ramifications of this ambiguity became clear in the series of cases that culminated in the Wilson v. Block decision in $1983 .{ }^{44}$ These suits revolved around what was then known as the Snow Bowl ski resort on the San Francisco Peaks, a mountain in northern Arizona immediately adjacent to the city of Flagstaff. At least thirteen Native nations recognize the San Francisco Peaks as sacred. At present the mountain lies beyond the geographic scope of any reservation, situated predominantly within the Coconino National Forest. Since 1937, the United States Forest Service (USFS) has permitted a recreational ski area on the slopes of the mountain. In 1983, the Hopi Tribe, the Navajo Medicinemen's Association, and other plaintiffs sought an injunction against a fifty-acre expansion of Snow Bowl's 777-acre ski area, contending that further expansion would abridge their religious freedom and violate AIRFA. When the case was decided against the plaintiffs in the District of Columbia Circuit Court, the majority decision largely pivoted on how the judges understood access and use of the site. Judge Lumbard opines that the plaintiffs' affidavits and other evidence:

[E]stablish the indispensability of the Peaks to the practice of the plaintiffs' religion. The Forest Service, however, has not denied the plaintiffs access to the Peaks, but instead permits them free entry onto the Peaks and does not interfere with their ceremonies or the collection of ceremonial objects. At the same time, the evidence does not show the indispensability of that small portion of the Peaks encompassed by the Snow Bowl permit area. The plaintiffs have not proven that expansion of the ski area will prevent them from performing ceremonies or collecting objects that can be performed or collected in the Snow Bowl but nowhere else. ${ }^{45}$

Although there is significantly more to the court's legal reasoning, this particular line of reasoning regarding AIRFA evinces how juridical interpretations of "access" to sacred sites and "use" of materials often marginalize indigenous concerns by discounting the indigenous ontologies which contextualize these concerns. The 
underlying logic of this specific passage is that because the ski area occupies only a portion of the mountain and practitioners could visit other parts of the mountain for prayers and ceremonial materials, indigenous peoples retained access to and use of the mountain for religious purposes and could perform ceremonies there, thus negating the claim under AIRFA. In regard to both "access" and "use" the Court posits divisible land and isolated impacts that, by implicitly relying upon cosmological understandings contrary to those of Native plaintiffs, effectively provincialize AIRFA in a decidedly Eurocentric manner.

This cosmological discrepancy is clear in the way in which "access" is treated in the above statement. While it is literally true that Hopi and Diné plaintiffs could still travel to the San Francisco Peaks - at least in the sense that the ski area's further development did not place an impenetrable barrier of concrete or steel around the entire mountain - this literal approach ignores the critical question of the ontological nature of a physical site. Because Lumbard was unconvinced that the 777 -acre Snow Bowl area was "indispensable," he concludes that access to the rest of the mountain for indigenous peoples was sufficient for religious practice. The implied argument in Lumbard's statement-that one portion can be developed without affecting the overall site-is that land is divisible, a line of reasoning which rests upon an implicit ideology of sacred sites as spatially delimited, identifiable, isolable, and, at least in some cases, fungible. ${ }^{46}$

Defining access in such a manner is problematic for several reasons. Most obviously, in an extremely skewed example of what Ayşen Eren refers to as "juridical knowledge-making" 47 and an oft-repeated pattern in sacred site litigation, such a definition establishes juridical authority over the requirements of indigenous religious practices to the detriment of claims by indigenous practitioners, the best judges of the religious significance of an area. ${ }^{48}$ Hopi and Diné statements in and out of the courtroom established that the further development of Snow Bowl would desecrate the entire mountain, reflecting a cosmology of the mountain as a single, holistic entity. ${ }^{49}$ Furthermore, defining access in this manner discounts indigenous ontologies out of hand. Within the worldviews presented by indigenous plaintiffs, the mountain is conceptualized as an entire holy mountain — not as a pie that can be divided according to its possible uses, nor a primarily neutral space on which shrines are located only at specific points. Although ceremonies can indeed be site-specific, such sites not only include the specific locations but also the entirety of the mountain; thus, curtailing usage of one specific area entails loss of access to the site in toto. While in the opinion of the Court protecting access and use could simply constitute lack of physical impediments to access, Native plaintiffs were evidently of the opinion that access and use should mean something more substantial. Within indigenous cosmologies, access to the mountain had been blocked, and was now being blocked further, as each inch of an indissoluble whole was taken away. ${ }^{50}$

The San Francisco Peaks, Dook'ooosłíid in Diné bizaad (Navajo), is fundamental and indispensable to the sacred Diné way of life. Dook'ooosłíid is the westernmost of sacred mountains at the cardinal directions which have been called among the "fundamental components that combine to form the most pervasive and integral aspects of 
Navajo cosmology. ${ }^{51}$ In addition, the mountain is a landscape of prayer, a source of critical ceremonial materials, and a gathering place of medicinal plants. ${ }^{52}$ As Mary H. Smith has argued, in this case plaintiffs viewed displacement from any part of the mountain with regard to ceremonial practice as a significant disruption not only of religious exercise, but of their cultural survival.53

In addition to its assumptions regarding access, the decision's logic concerning use or collection of materials is also problematic. Importantly, moreover, this seemed to be an example of what Cynthia Thorley Andreason phrases "governmental use of property in ways that effectively makes Indian religious uses of the land impossible," 54 and thus arguably constituted an AIRFA violation. Lumbard suggests that use and free exercise was permitted because federal land managers allowed collection of materials and ceremonies. Central to the indigenous plaintiffs' claim was the specific contention that the expansion of the resort would impinge upon the isolation requisite for proper ceremonial observance, 55 and, moreover, that the development would significantly curtail prayer, ceremonial, and gathering activities on the mountain and "expansion of the ski area will destroy the natural conditions necessary for prayers and ceremonies to be effective." 56 Then-chair of the Hopi tribe Abbott Sekaquaptewa additionally stated that if the expansion occurred "we will not be able successfully to teach our people that this is a sacred place ... our people will not accept the view that this is the sacred Home of the Kachinas,"57 Diné plaintiffs, in turn, held that "artificial development of the Peaks would impair the Peaks' healing power." ${ }^{58}$ Such statements prompt us to inquire whether a site is still "accessible" and "usable" if it has become fundamentally desecrated for those who utilize it. Rather than grappling with this critical question of conflicting ontology, the decision in Wilson v. Block simply assumes the falsity of Native American beliefs regarding the usability of the site-a result of the justices' failure to recognize any visible or legible impact.

This rather narrow interpretation of AIRFA is all the more tragic in light of the act's initial promise; Suzan Shown Harjo notes, "After generations of traditional Native religions being driven underground or to extinction, and traditional practitioners being stigmatized as outlaws, AIRFA was lauded as a much needed and welcome policy."59 Yet among other problems, a restricted and literalistic usage in the courts of the terms use and access has significantly muted the act's effectiveness as a policy tool for Native peoples concerned about cultural landscapes. Perhaps unsurprisingly, in other court cases involving or drawing upon AIRFA, judges have regularly adopted a narrow definition of access or use. ${ }^{60}$

\section{RFRA and "Substantial Burden"}

A second definitional issue with political ramifications lies in the phrase "substantial burden," a linchpin in the Religious Freedom Restoration Act of 1993 (RFRA), which is often utilized in court cases involving sacred sites. ${ }^{61}$ RFRA states that the federal government shall refrain from "substantially burdening a person's exercise of religion" unless "the burden to the person: (1) furthers a compelling government interest; and (2) is the least restrictive means of furthering that ... interest." 62 I am certainly not 
the first scholar to express the opinion that the interpretation and implementation of this act has not lent itself well to the protection of sacred lands. ${ }^{63}$ While RFRA could, in theory, provide powerful leverage for tribes seeking to gain legal protections for cultural landscapes, the short, three-sentence legislation leaves unanswered the pivotal question of what constitutes "substantial burden." To the extent that such a term is ambiguous, the privilege of establishing its definition lies in the hands of what Walter R. Echo-Hawk and others have referred to as the "courts of the conqueror," 64

An ongoing conflict over artificial snowmaking at the ski resort currently occupying the San Francisco Peaks illustrates the disastrousness of such an unclear standard and the ways in which it can be utilized to perpetuate colonial land-use regimes. This ski resort, now under new ownership, is the same one whose previous expansion prompted the Wilson v. Block case. Conflict over this space renewed in 1998 when Arizona Snowbowl announced plans for additional expansion and then accelerated in 2004 with the declaration that they would seek approval to commence artificial snowmaking at the resort in an attempt to remain profitable after drought shortened its seasons. In lieu of potable water, Arizona Snowbowl proposed utilizing reclaimed wastewater that would be treated biologically, chemically, and radiologically to reduce the levels of contamination from previous use. The USFS approved Snowbowl's snowmaking/expansion proposal in 2005. Shortly thereafter, several tribes, including the Navajo Nation, filed suit against the Forest Service; among other claims, the tribal plaintiffs contended that snowmaking and expansion entailed a violation of RFRA.

The Navajo Nation v. USFS case underwent several shifts in fate. ${ }^{65}$ While the District Court initially decided against the tribes in regards to the RFRA claim, on appeal the Ninth Circuit panel entered a finding in favor of the tribes, only for that decision to be overturned on review by the Ninth Circuit Court en banc. The majority decision held that because tribes had not been coerced into violation of beliefs via sanction or the conditioning of a government benefit, snowmaking did not impose substantial burden on their exercise of religion. ${ }^{66}$ In this vein, Judge Bea wrote

The only effect of the proposed upgrades is on the Plaintiffs' subjective, emotional religious experience. That is, the presence of recycled wastewater on the Peaks is offensive to the Plaintiffs' religious sensibilities. To Plaintiffs, it will spiritually desecrate a sacred mountain and will decrease the spiritual fulfillment they get from practicing their religion on the mountain. Nevertheless, under Supreme Court precedent, the diminishment of spiritual fulfillment-serious though it may be-is not a "substantial burden" on the free exercise of religion. ${ }^{67}$

Here and elsewhere, the justices in this decision draw a contrast between the emotional and subjective "experience" of religion and its practice, peculiarly arguing that experience of religion is not fundamental to its exercise. ${ }^{68}$ Distinguishing religious "experience" from its "exercise" allowed justices to present a corresponding dichotomy, that of "offense" versus "burden," and thus, presuming that "burden" is something more objective than "subjective, emotional religious experience," to hypothesize that offense is legally permissible. Such a distinction contains within it the a priori and implicit conclusion that indigenous people's stated concerns about desecration and contamination of 
a space are not objective reality, but merely subjective belief; that actions which Native American practitioners recognize as actual degradation of their sacred spaces are, in fact, simply an "offense [of] sensibilities." By contrast, that which constitutes actual infringement is left to the interpretation of non-Native judges (who are often rooted in ontologies and epistemologies that fragment and divide land) thus marginalizing indigenous viewpoints on causality and ecology, spirit and matter, in favor of that of the justices in an "exclusionary hierarchy of knowing and being." 69 To define plaintiff claims in sacred sites cases as merely "subjective" is a means of concentrating knowledge-power, controlling the boundaries of truth in such a way as to exclude troublesome indigenes.

Proceeding from this initial point of juridical knowledge-making, "burden" is then discussed in terms of the types of physical effects judges recognize in their own understandings of the natural world, informed by eco-hegemonic settler ecologies. Thus, with regard to snowmaking in Navajo Nation v. USFS, for example, the majority states that "there are no plants, springs, natural resources, shrines with religious significance, or religious ceremonies that would be physically affected by the use of such artificial snow. No plants would be destroyed or stunted; no springs polluted; no places of worship made inaccessible, or liturgy modified."70 The empirical grounds used when determining if a ceremony has been physically affected, a spring polluted, a site made inaccessible, or indeed the very nature of physical effects, is left unpacked - a "black box" in the colonial court system. While the juridical ontologies of the Dine and the United States clearly differ on how pollution occurs, and in case law the US view has prevailed, this exclusion has not been acknowledged.

Since 2009 I have conducted ethnographic, sociolinguistic, and archival research on popular sentiments regarding perceptions of snowmaking and the tactics utilized by community organizers opposed to the ski resort expansion. ${ }^{71}$ My ethnographic research suggests that snowmaking impacts Diné religious practice in numerous ways, of which I will consider three. In outlining these, I note that like other traditions, Diné traditionalism is a diverse body of thought and practice; as Robert S. McPherson reminds us, "interpretation of Navajo sacred geography is dependent upon the teachings and ceremonial knowledge of the individual." 72 In this discussion, I am certainly not claiming that my interviewees' thoughts are universally held among Diné people, but rather that we should attend to these statements because they are grounded within traditionalist discourses and ceremonies salient across Diné society. They also corroborate what other Diné have said both in and out of the courtroom.

One Diné herbal healer with whom I spoke stated that, were the snowmaking to proceed, she would no longer collect healing plants on the mountain as these would be polluted. Her statement corresponds with the repeated statements of other interview participants that reclaimed wastewater contains human waste, ceremonially impure influences, and artificial chemicals. Indeed, despite the legal categorization of the water as "A+" quality by the Arizona Department of Environmental Quality (ADEQ),73 such concerns about reclaimed wastewater are well-documented by environmental scientists, who have found that among other contaminants it may contain endocrine disruptors, pharmaceuticals, carcinogens, and caffeine, ${ }^{74}$ in addition to posing a risk of nitrogen and phosphorous contamination to plants through snowdrift. ${ }^{75} \mathrm{I}$ would argue 
that causing medicinal plants to become contaminated so that healers cannot use them creates a substantial burden on religious practice, especially given that in Diné society healing and the sacred are closely interwoven.

Other concerns involve the ability to pray on Dook'ooosłííd. Many Diné people visit this mountain for the purpose of prayer to Diyin Dinée (Holy People) and animals, among them Rochelle, a Diné woman from nearby Leupp, who said that snowmaking would impact even the possibility of prayers on Dook'ooosłíld. Rochelle stated that because prayers to Diyin Dineé must be done with an offering (such as tadadiin, or corn pollen) in an undisturbed location, and because snowmaking/expansion would disturb the entire mountain, it followed that prayers would no longer be able to be done properly, and then "everything is going to leave-the animals, the gods."76 In her view the ramifications to her religious practice were drastic.

Finally, one of the concerns about snowmaking that is most often expressed is its contamination of ceremonial materials necessary for the Blessingway, which has been called the backbone of Diné ceremonies. ${ }^{77}$ Medicine people or other elders hold a bundle of these ceremonial materials, ${ }^{78}$ among which the bundle must contain soil from the sacred mountains which correspond to the cardinal directions, including Dook'ooosłíid as the mountain of the west. Soil from these mountains is therefore one of the most critical ceremonial materials in Diné religious practice. Significantly, it was the opinion of two separate interview participants, Tom and Adrian, both sons of hathaalii (chanters/medicine people), that snowmaking with reclaimed water from Flagstaff would contaminate the soil of this mountain because its use in area hospitals means that some of the water has been in contact with the dead. ${ }^{79}$ It is possible that placing death on soil utilized to promote life through the Blessingway is a cause of their concern, as well as Diné ideologies regarding unnatural death. ${ }^{80}$ The reclaimed water, Tom notes, has also been in contact with menstrual fluids, which is problematic. ${ }^{81}$ Schwarz has written at length about the ways in which menstrual fluid is ritually incompatible with the Blessingway if precautions are not taken. ${ }^{82}$ Influences which are not to be combined with Blessingway materials - menstruation and death-would negatively affect the mountain soil. As such, and particularly in light of the cumulative impacts of desecrating activities on the other sacred mountains, the ceremonies which depend on this soil would be less efficacious, according to Tom, who also postulated that the decline of ceremonial efficacy would lead Diné people to self-destructive paths, which he asserted was a form of cultural genocide. ${ }^{83}$

Do these three instances-disruption of prayer practices, pollution of medicinal plants, and contamination of soil essential to religious ceremony-demonstrate a substantial burden on the religious activity of Diné people, as my research strongly suggests? ${ }^{84}$ Healing, prayer, and the Blessingway are all significant, indeed central, practices in Diné religious activity. In fact, the USFS' Environmental Impact Statement for the expansion tacitly acknowledges the presence of significant religious burdens, stating that "snowmaking and expansion of facilities, especially the use of reclaimed water, would contaminate the natural resources needed to perform the required ceremonies that have been, and continue to be, the basis for the cultural identity for many of these tribes." 85 
How, then, to account for the Circuit Court ruling that snowmaking solely constituted an "offense" or a "decrease [of] spiritual fulfillment"? There is no single answer to this question. Perhaps we should expect nothing different from a settler court system. ${ }^{86}$ In addition, a central problem for this case is the court's reading of "substantial burden" as, again, being primarily about coercion or conditioning of government benefit. However, there is also an underlying ontological politics at play, ${ }^{87}$ a hierarchy of epistemologies reflective of the colonial marginalization of indigenous ways of knowing which receives scarce formal mention in court cases such as this, but which can structure the entire proceedings. The problem seemed not to lie in the claim that Diné held the land as sacred, which was acknowledged explicitly by the judges, but rather how land can be impacted and thus how religious practices inextricably intertwined with that land can be burdened.

The argument put forward by the justices relied upon the presupposition that impacts of snowmaking would be confined to the "small" area of the resort. Such a conceptualization is predicated upon a model of geometric, divisible space. By contrast, Diné arguments about contamination of the mountain rest upon a different set of cosmological principles, including an understanding that landscapes are holistic and indivisible, and in fact are like a human body. Diné people have spoken to me of the mountain in embodied terms such as "like a Holy Being standing there" and "Mother Dookooosłíd," capable of feeling physical pain as well as emotions. ${ }^{88}$ The impact of snowmaking in such a view cannot be thought to be confined to one part of the mountain any more than pain in one part of a body can be easily separated from the rest. As one interviewee articulated, "1 percent! That is like saying 'I am going to inject this drug into you, but only [at] 1 percent of your skin'; but it affects the whole body." Another Diné man stated, "This is like telling someone 'I am going to put this chemical mixture on you, but just a small part, do not worry." From these Diné individuals' perspectives, snowmaking at one section of the mountain would indeed affect the entire area.

To some degree, then, the politically expedient (but culturally parochial) understanding of land as divisible, embodied in certain aspects of federal land management, stands in stark contrast to Diné understanding of the land; one is predicated on geometric understandings of quantifiable and divisible space, while the other is predicated on the inviolability and interconnectedness of a living body. Such ontological discrepancies are to be expected in multicultural politics, but RFRA, at least in practical usage, is in urgent need of decolonization to the extent that its interpreters presuppose the truth of one worldview (that of settlers) over another (Diné) and judge impacts to religious practice accordingly.

In Navajo Nation v. USFS the justices' decision on burden was also restricted through its reliance on certain actors and epistemologies over others in measuring pollution. The Arizona Department of Environmental Quality (ADEQ)'s categorization of reclaimed water as "A+" in this case operated as an instrument of governmentality accepted by the courts which differed sharply from Diné truth claims about this water. ${ }^{89}$ Diné local knowledge about contaminants, and especially those untestable by laboratory means, such as the contamination of death, were implied to be cultural/subjective/experiential rather than a verifiable statement of reality, despite 
their rootedness in observable fact (that some of the water will have gone through hospitals). In the majority opinion, the "true" nature of contamination or purity of water was to be ascertained via the ADEQ decision, which focused in technocratic terms on specific chemicals, when found at specific levels and in specific tests.

I have identified only three effects of snowmaking on prayers, ceremonies, and healing posited by Diné people. There are many more. I highlight these impacts not to be a voice for people whose story this is and who have already expressed themselves, but instead to point towards one reason why their voices, and those of other indigenous persons, are not being heard in RFRA and other sacred site cases. As this case illustrates, current interpretations and implementations of RFRA can contain unspoken assumptions: culture-based, non-Native understandings of how lands physically operate and what can contaminate them (and how that can be known), thereby undercutting indigenous claims to a real knowledge of their own spaces. In the case of snowmaking, it is an intellectual colonialism that exacerbates and facilitates the more obvious resource colonialism. The definition within RFRA of "substantial burden" ignores these intercultural complexities; and, as seen above with both access and use, where there is ambiguity within the law, resource extraction often predominates over indigenous interests. We cannot pretend these terms are apolitical or acultural when their interpretations are so clearly cultural and their impacts so deeply political.

\section{CONCLUSION}

In late 2017, the city council of Flagstaff, Arizona, adopted a resolution similar to those of several other cities across the United States that spoke against the Dakota Access Pipeline. In it, the council declares "The City of Flagstaff recognizes the unique relationship Tribal Nations possess with the United States as one of political equality, among sovereigns, and calls upon the United States and the Army Corps of Engineers to obtain the free, prior and informed consent of the Standing Rock Sioux Tribe, prior to taking any federal action regarding the DAPL that would harm or destroy the Tribe's ancestral lands, waters and sacred sites." 90

Flagstaff's resolution highlights a varied and, some argue, contradictory approach taken by the local government towards Native American sacred sites, a willingness to condemn desecration from a distance while enabling it near at hand. For example, the city of Flagstaff stands at the center of the snowmaking controversy that forms much of the framework for this paper. To the consternation of many of its citizens, Flagstaff's municipal government has a contract to sell reclaimed wastewater to Arizona Snowbowl for the purposes of the opposed snowmaking. In regards to the Dakota Access resolution, the city council originally (under prompting of progressive council members) considered the inclusion of language in the above resolution that would more directly connect the Dakota Access Pipeline issue with the ongoing human rights issue of snowmaking; however, this language was omitted from the final declaration. ${ }^{91}$

At the time, a Diné colleague of mine expressed a sense of outrage at the hypocrisy of the Flagstaff city government, which could be seen as facilitating snowmaking on 
the San Francisco Peaks even as it condemned the Dakota Access Pipeline on the grounds of tribal sovereignty and sacred lands. Others expressed the view that the declaration was a positive step-but only a step. This seems a fitting example of the complexities involved in sacred site policy in the United States under conditions of resource colonialism: with one hand, governments condemn and seek to prevent loss of Native American religious freedoms, yet with the other hand, those same governments on the city, state, and federal level facilitate and in some cases directly benefit from the despoliation of indigenous lands essential to said freedoms. It hardly needs mentioning that such is a conflicted, if not compromised, position. ${ }^{92}$

Given such a position and the conflicting demands at the highest levels, it is perhaps not surprising that the laws and policies relevant to Native American sacred lands contain vague terms and phrases that are therefore problematic when interpreted during actual indigenous land battles in colonial courtrooms. AIRFA, while vitally important, nonetheless leaves unanswered the question of what constitutes access to sacred sites, aiding judges seeking to dispel Native claims. RFRA, although it contains the important and potentially useful provision regarding substantial burdens on religious practice, also leaves key questions essentially unanswered: who defines the burden, and upon what ontological grounds?

Colonialism both necessitates and constrains sacred land policy and laws. The direct assault on cultural landscapes due to resource extraction, tourism, and settler occupation lead to a situation in which clear laws and policies are necessary to achieve even the most basic of protections for sacred places located on public lands. Yet, at the same time, colonialism entails an ideological imperialism which tends to marginalize Native American truth claims and restrict the potential of the very sacred land policy it enjoins. Substantial burden under RFRA, and infringement of religious freedom more generally, comes to be understood in light of hegemonic understandings of land and pollution that downplay the ways in which a mountain is like a body and polluted snow like a poison.

Thus, there are significant obstacles in the utilization of sacred site policies and laws for the protection of Native sacred lands: a combination of vague (but seemingly neutral) legal language interpreted by a largely non-Native judiciary who presuppose assumptions about land directly in contrast to those of indigenous peoples in the courtroom; in effect, a cooperative colonialism between congress and the courts. These obstacles nonetheless do not negate the significant victories gained through these policies and laws. These legalities can, and sometimes do, act as a check against aggressive infringement of Native American religious practices on public land; they can also act as policy guides for positive decisions in other pathways. However, attention to the realities and perspectives of Native Americans' ecologies would tremendously strengthen the effectiveness of these laws and policies. There is significant potential in these laws, but the same colonial context which necessitates them also limits them, and until this is recognized and explicitly addressed their promise will remain unfulfilled, in some cases constituting mere formalities, boxes to check rather than effective protection for practitioners of land-based religions. Without sacred site legislation providing reliable courtroom mechanisms, tribes are often left in what Hardgrave describes as a "luck 
of the draw" situation as they must utilize the "agency approach" - direct consultation for protection of sacred landscapes with federal land managers, where results will vary both by area and agency. ${ }^{93}$

Until the patchwork of sacred site policy and law has been further refined, demonstrations outside of the courthouse may prove more effective than sacred land laws inside it. In the case of snowmaking, outside the courtroom there were and are many individuals, both indigenous and non-Native, who engage in various types of organizing and demonstration to oppose the desecration of the mountain. Among other efforts, the grassroots movement has brought significant attention to the threat to the mountain, arguably brought about a more robust environmental-impact assessment process, and, at various times, delayed construction.

The recent conflict over the pipeline at Standing Rock, an impetus if not a direct focus of this article, is not simply a court case, but first and foremost a grassroots movement of resistance, one that ultimately incorporated thousands from across the United States and globe from dozens of indigenous nations as well as non-Native people. Through demonstrations, social media, and direct action, national attention was brought to bear on what typically remains unseen-Native sacred land battlesgaining political momentum, construction delays, and for a brief time, a reopening of the NEPA process. Perhaps a more significant, long-term gain has been further strengthening public awareness of pantribal activism in defense of Native lands, which may very well bolster other sacred land efforts. This type of advocacy can not only bring results, but may be necessary: the sacred land policies and laws of today cannot become the recourse they were intended to be if those laws continue to be interpreted subject to ideologies directly countering the specific religious expressions they were designed to protect.

\section{Acknowledgments}

The author would like to express his deep gratitude to all those who have contributed to this work, most significantly Diné interlocutors and friends living in Arizona and the Navajo Nation who have shared their understandings and opinions of sacred-site issues with me. Furthermore, I would like to thank the Honorable Robert Yazzie, the family of Tim Nelson, and Charleen Dunstan. I would also like to thank the two anonymous reviewers, whose insights greatly enriched the writing process. However, any errors and misinterpretations are entirely my own.

Portions of research drawn on in this paper were funded by the Jacobs Research Funds, the Charles Redd Center for Western Studies, the David M. Kennedy Center for International Studies, the Mark Diamond Research Fund, and the McNulty Grant for Cultural Studies. 


\section{NOTES}

1. I am using "landscape" primarily in the sense of culturally and discursively meaningful spaces (for a classic early articulation of this concept, see Thomas Greider and Lorraine Garkovich, "Landscapes: The Social Construction of Nature and the Environment," Rural Sociology 59, no. 1 (1994): 1-24, https://doi.org/10.1111/j.1549-0831.1994.tb00519.x). However, I am also referring to the idea that sacred spaces are not isolated (as the term site sometimes implies), but instead interrelated across the land, as in Klara Bonsack Kelley and Harris Francis, Navajo Sacred Places (Bloomington: Indiana University Press, 1994), and Keith H. Basso, Wisdom Sits in Places: Language and Landscape among the Western Apache (Albuquerque: University of New Mexico Press, 1996).

2. For the purposes of this article, the term law is specifically applied to congressional legislation, while policy encompasses other government instruments such as executive orders.

3. This paper focuses on sacred land policy and laws specifically as they are utilized by tribes in the courtroom after an adverse decision has been reached by a federal agency. Of course, litigation is not the only manner in which tribes may seek to influence a federal agency to prevent desecrating actions at a sacred site. Marcia Yablon highlights several cases in which federal agencies have accommodated or made arrangements for indigenous sacred areas in consultation with tribes, often due to an agency's voluntary efforts to comply with statutory requirements; see Yablon, "Property Rights and Sacred Sites: Federal Regulatory Responses to American Indian Religious Claims on Public Land," The Yale Law Journal 113, no. 7 (2004): 1646-52, https://doi.org/10.2307/4135775. At the same time, it has also been argued that relying upon agencies to protect sacred lands leads to what has been described as a "luck of the draw" situation, due to the variability both within and between agencies in following these mandates; Joseph E. Hardgrave, ExpressO, "Hell on Earth: The Desecration of Sacred Indian Land Needs a Final Solution" (March 2007), 13, https://works.bepress.com/joe_hardgrave $/ 2 /$.

4. For a discussion of free-exercise precedents and their relevance to sacred land litigation, see Camala Collins, "No More Religious Protection: The Impact of Lyng v. Nortbwest Indian Cemetery Protective Ass'n," Washington University Journal of Urban and Contemporary Law 38, no. 16 (1990), https://openscholarship.wustl.edu/law_urbanlaw/vol38/iss1/16. Despite being published prior to the Religious Freedom Restoration Act and associated cases, much of Collins's conceptualizations of free exercise remain relevant in the adjudication of sacred land claims.

5. Sharon Milholland, "In the Eyes of the Beholder: Understanding and Resolving Incompatible Ideologies and Languages in US Environmental and Cultural laws in Relationship to Navajo Sacred Lands," American Indian Culture and Research Journal 34, no. 2 (2010): 103, https://doi. org/10.17953/aicr.34.2.y8nh212075112115.

6. Ibid, 104.

7. John R. Welch, Ramon Riley, and Michael V. Nixon, "Discretionary Desecration: Dził Nchaa Si An (Mount Graham) and Federal Agency Decisions Affecting American Indian Sacred Sites," American Indian Culture and Research Journal 33, no. 4 (2009): 29, https://doi.org/10.17953/ aicr.33.4.2866316711817855. The authors note that attempts to legally define and protect sacred sites "have defied conscientious attempts to clarify terms."

8. Karsten A. Schultz, "Decolonizing Political Ecology: Ontology, Technology, and 'Critical' Enchantment," Journal of Political Ecology 24 (2017): 110, http://jpe.library.arizona.edu/volume_24/ Schulz.pdf.

9. Robert S. Michaelson, “Civil Rights, Indian Rites," Society 21, no. 4 (1984): 45, https://doi. org/10.1007/BF02695100; Welch, Riley, and Nixon, "Discretionary Desecration," 34; Yablon, "Property Rights and Sacred Sites," 1638.

10. United States Constitution, amendment I. 
11. Suzan Shown Harjo, "American Indian Religious Freedom Act after Twenty-Five Years: An Introduction," Wicazo Sa Review 19, no. 2 (2004): 130, https://doi.org/10.1353/wic.2004.0019. Harjo highlights, for example, the Civilization Regulations, which outlawed many indigenous religious practices in the 1880s and were not rescinded until 1936.

12. Yablon, "Property Rights and Sacred Sites," 1624.

13. N. Bruce Duthu, American Indians and the Law (New York: Viking Penguin, 2008), 110.

14. National Historic Preservation Act of 1966, Pub. L. 89-665, 16 USC Ch. 1A, subch. II (1966).

15. National Environmental Policy Act. Pub. L. 91-190, 42 USC $₫ 4321$ (1969).

16. American Indian Religious Freedom Act, Pub. L. No. 95-341, 42 USC 1996 (1978).

17. Archaeological Resources Protection Act. Pub. L. 96-95, 16 USC 470 (1979).

18. The Native American Graves Protection and Repatriation Act, Pub. L. No. 101-601,

25 USC ch. $32 \S 3001$, et seq. (1990).

19. Religious Freedom Restoration Act, Pub. L. No. 013-141, 42 USC 2000bb (1993). This act should not be confused with state-level bills of the same name passed in the 2010s.

20. Exec. Order. No. 13,007, 61 Fed. Reg. 104 (May 24, 1996).

21. While this article focuses primarily on ambiguities and their implications within AIRFA and RFRA, there is a significant literature on different sacred site laws, or that analyze AIRFA and RFRA through different lenses. For example, as previously mentioned, Milholland draws on the concept of incommensurability and outlines "incompatible ideologies and languages" within EO 13007, AIRFA, NEPA, NHPA, and RFRA; see Milholland, "In the Eyes of the Beholder," 104. Robert Charles Ward argues that rather than providing substantive protections NHPA is largely procedural, while among some practitioners ARPA raises concerns about sharing sacred knowledge about site location with government agencies; see Ward, "The Spirits Will Leave: Preventing the Desecration and Destruction of Native American Sacred Sites on Federal Land," Ecology Law Quarterly 19 no. 4 (1992), https://doi.org/10.15779/Z38FZ56. Barbara J. Mills and T. J. Ferguson present a somewhat mixed portrait, outlining significant work done under NHPA auspices by the Zuni Archaeological Program to protect Zuni sites, yet also noting certain limitations of the Zuni Tribe's strategy; see Mills and Ferguson, "Preservation and Research of Sacred Sites by the Zuni Indian Tribe of New Mexico," Human Organization 57, no. 1 (1998), https://doi.org/10.17730/ humo.57.1.k22560377478330h.

22. Harjo, "American Indian Religious Freedom Act after Twenty-Five Years," 130-34.

23. Robert S. Michaelson, "Dirt in the Courtroom: Indian Land Claims and American Property Rights," in American Sacred Space, ed. David Chidester and Edward T. Linenthal (Bloomington: Indiana University Press, 1995, 45.

24. Throughout this paper I frequently refer to indigenous nations' sacred practices using the terms religion or religious, although during my research I often encountered participants using the terms way of life or lifeway. It is self-evident that indigenous sacred ceremonies, stories, teachings, and practices meet both scholarly and legal definitions of "religion"; in this article I favor "religion" intentionally in order to directly articulate this discussion to pertinent religious freedom legislation often relied upon to protect sacred lands.

25. Tom Holm, J. Diane Pearson, and Ben Chavis, "Peoplehood: A Model for the Extension of Sovereignty in American Indian Studies," Wicazo Sa Review 18, no. 1 (2003): 12-13, https://doi. org/10.1353/wic.2003.0004.

26. Donald Grinde, "Understanding Traditional American Indian Ecocentricity," paper presented at "Environmental Studies: An Interdisciplinary Workshop," Buffalo, NY, November 8, 2012. 
27. Walter R. Echo-Hawk, "Under Native American Skies," The George Wright Forum 26, no. 3 (2009): 63 .

28. Gregory Cajete, Look to the Mountain: An Ecology of Indigenous Education (Durango: Kivakí Press, 1994), 21.

29. See Rebecca T. [sic] Tsosie, "Conflict between the Public Trust and the Indian Trust Doctrines: Federal Public Land Policy and Native Indians," Tulsa Law Review 39, no. 2 (2003): 271, 293, https://digitalcommons.law.utulsa.edu/tlr/vol39/iss2/3/.

30. Uranium mining was proposed at Mt. Taylor in New Mexico, for example; see Melinda Harm Benson, "Mining Sacred Space: Law's Enactment of Competing Ontologies in the American West," Environment and Planning A 44, no. 6 (2012): 1443-58, https://doi.org/10.1068/a44579.

31. For example, the G-O Logging Road through the Chimney Rock/High Country area of the Six Rivers National Forest was the focus of the Lyng v. Northwest Indian Cemetery Protective Association litigation. See Howard J. Vogel, "The Clash of Stories at Chimney Rock: A Narrative Approach to Cultural Conflict Over Native American Sacred Sites on Public Land," Santa Clara Law Review 41, no. 3 (2002): 757-806, 780-781, https://doi.org/10.2307/20070625.

32. For instance, a number of nations have sacred ceremonies and stories associated with Mateo Tipila, or Bear's Lodge, in Wyoming. As a national monument, the site is favored by rock climbers, and many Native Americans have expressed opposition to the disruptiveness and disrespect associated with rock climbing. This eventually prompted the voluntary June climbing ban. See Joel Brady, "Land is Itself a Sacred, Living Being': Native American Sacred Site Protection on Federal Public Lands Amidst the Shadows of Bear Lodge," American Indian Law Review 24, no. 1 (1999): 165, https:// doi.org/10.2307/20070625; and Vogel, "The Clash of Stories at Chimney Rock," 771. One of the better-known examples of sacred site destruction for governmental use is the flooding of the Rainbow Bridge area in the creation of Lake Powell, and the construction of boating facilities at the adjacent Glen Canyon National Recreation Area. Not only did this prevent access to ceremonial areas, it was also regarded by local Diné as the drowning of Holy Beings and desecration and destruction of sacred sites. See Howard Stambor, "Manifest Destiny and American Indian Religious Freedom: Sequoyah, Badoni, and the Drowned Gods," American Indian Law Review 10, no. 1 (1982): 84, https://doi. org $/ 10.2307 / 20068205$.

33. American Indian Religious Freedom Act, Pub. L. No. 95-341, 42 U.S.C. 1996 (1978), $§ 1$.

34. Cynthia Thorley Andreason, "Indian Worship v. Government Development: A New Breed of Religion Cases," Utab Law Review 1984, no. 2 (1984): 321.

35. American Indian Religious Freedom Act, Pub. L. No. 95-341, 42 U.S.C. 1996 (1978), $₫ 1$.

36. See, for example, Michaelson, "Dirt in the Courtroom," 43; Stambor, "Manifest Destiny and American Indian Religious Freedom," 84.

37. In Northwest Indian Cemetery Protective Association v. Peterson, 795 F.2d at 693 (9th Cir. 1986), the Ninth Circuit justices stated that the road would "virtually destroy the ... Indians' ability to practice their religion." In the Supreme Court, Justice O'Connor, writing for the majority, more conservatively argued that "we can assume that the threat to the efficacy of at least some religious practices is extremely grave”; Lyng v. Northwest Indian Cemetery Protective Association, 485 U.S. at 451 (1987).

38. Lyng v. Northwest Indian Cemetery Protective Association.

39. Wilson v. Block, 708 F.2d 735 (D.C. Cir. 1983) at 748.

40. Harjo, "American Indian Religious Freedom Act after Twenty-Five Years," 124-36. One of the principal advocates for the passage of AIRFA, Harjo has written that "there is much to do in order to fulfill AIRFA's promise to preserve and protect Native American religious freedom" (124) and that "the failure of Congress and five administrations to create a cause of action for sacred places protection is the most glaring item on AIRFA's unfinished agenda" (136). At the same time, Harjo 
notes that AIRFA has been more effective as a statement of policy which has guided certain positive government-to-government actions, including the return of several traditional and customary places either directly to tribes or as comanagement agreements, and also indirectly led to the passage of NAGPRA $(124,132-33)$.

41. Ibid., 134; Walter R. Echo-Hawk, Lenny Foster, Alan Parker, and Wallace Coffey, "Issues in the Implementation of the American Indian Religious Freedom Act: Panel Discussion," Wicazo Sa Review 19, no. 2 (2004): 155, https://doi.org/10.1353/wic.2004.0017.

42. American Indian Religious Freedom Act, Pub. L. No. 95-341, 42 U.S.C. 1996 (1978), $\$ 1$ (emphasis added). Note that Executive Order 13007 ("Indian Sacred Sites") similarly states that federal agencies with authority over public lands shall "accommodate access to and ceremonial use of Indian sacred sites by Indian religious practitioners," Executive Order No. 13,007, 61 Fed. Reg. 104 (May 24, 1996), §1.

43. American Indian Religious Freedom Act, Pub. L. No. 95-341, 42 USC 1996 (1978), $\$ 1$.

44. Wilson v. Block.

45. Ibid., 744 n5.

46. This decision and its attendant logic contributed to an unfortunate, and widely critiqued, centrality test in sacred site litigation: the concept that sacred areas must be proven to be indispensable in the sense of being the only location at which site-specific ceremonies can be performed. Celia Byler, "Free Access or Free Exercise? A Choice Between Mineral Development and American Indian Sacred Site Preservation on Public Lands," Connecticut Law Review 22, no. 2 (1990): 414; Charles Miller, "The Navajo-Hopi Relocation Act and the First Amendment Free Exercise Clause," University of San Francisco Law Review 23 no. 1 (1988): 105; Erica R. Rosenberg, "Native Americans' Access to Religious Sites: Underprotected Under the Free Exercise Clause?" Boston College Law Review 26 (1985): 487; Timothy A. Wiseman, "Why the Religious Freedom Restoration Act Cannot Protect Sacred Sites," American Indian Law Journal 5, no. 1 (2017): 151. This demand is problematic for a variety of reasons, including that it ignores the reality of practical and religious reasons indigenous nations may not wish to identify specific ceremonial sites within broader sacred landscapes.

47. Ayșen Eren, "The Political Ecology of Uncertainty: The Production of Truth by Juridical Practices in Hydropower Development," Journal of Political Ecology 24 (2017): 386, http://jpe.library. arizona.edu/volume_24/Eren.pdf.

48. Mary H. Smith, "Wilson v. Block," Natural Resources Journal 26, no. 1 (1986): 183.

49. Rosenberg, "Native Americans' Access to Religious Sites," 487.

50. As noted by Luralene D. Tapahe, this prevailing interpretation of access by the majority justices, not limited to this case, reflects a "theological bias" in sacred site litigation. Tapahe, "After the Religious Freedom Restoration Act: Still No Equal Protection for First America Worshipers," New Mexico Law Review 24, no. 2 (1994): 341.

51. Maureen T. Schwarz, "I Choose Life": Navajo Perspectives on Medical and Religious Pluralism (Norman: University of Oklahoma Press, 2008), 22.

52. I have written in more detail about the role of this mountain in Diné life in my $\mathrm{PhD}$ dissertation, "Toxic Desecration: Science and the Sacred in Navajo Environmentalism," State University of New York at Buffalo, 2016. See also Adam Dunstan, "With Anything Manmade there is Going to be Danger': The Cultural Context of Navajo Opinions regarding Snowmaking on the San Francisco Peaks," Indigenous Policy Journal 21, no. 2 (2010): 1-6, and "What Was Damaged? Taking Sacred Ecology into Account in Environmental Impact Assessment," Indigenous Policy Journal 22, no. 4 (2012): 12-22. For other scholars who have written about Diné sacred mountains in general and, less frequently, particular mountains, see Stephen Jett, "An Introduction to Navajo Sacred Places," Journal of Cultural Geography 13, no. 1 (1992): 29-39, https://doi.org/10.1080/08873639209478398; Klara Bonsack Kelley and Harris Francis, Navajo Sacred Places (Bloomington: Indiana University Press, 
1994); Robert S. McPherson, Sacred Land, Sacred View: Navajo Perceptions of the Four Corners Region (Provo, UT: Charles Redd Center for Western Studies, 1992); and Gladys A. Reichard, Navajo Religion: A Study of Symbolism (New York: Pantheon, 196 [1950]), among others.

53. Smith, "Wilson v. Block," 183.

54. Andreason, "Indian Worship v. Government Development," 313.

55. Ibid., 321; Michaelson, "Civil Rights, Indian Rites," 42.

56. Wilson v. Block.

57. Ibid., $740 \mathrm{n} 2$.

58. Ibid., 738 .

59. Harjo, "American Indian Religious Freedom Act after Twenty-Five Years," 130.

60. Narrow interpretations of "access" are not unique to the Hopi v. Block case. For example, in Sequoyab v. Tennessee Valley Authority, while the AIRFA claim was preempted due to the Energy and Water Development Appropriation Bill, the justices nonetheless obliquely engaged with the question of access in their consideration of the First Amendment free exercise claim. In this case, the majority emphasized that the dam would constitute the "flooding of a particular place" and the "exact location" (emphasis added) and explicitly contrasted this in the next sentence with the idea that the "entire Valley is sacred." They then argue that these specific locations within the valley had not been proven indispensable, and that usage of those sites for ceremony or collection instead reflected "preference." Sequoyah v. Tennessee Valley Authority, 620 F.2d 1159 at 1163-64 (6th Cir. 1980). Meanwhile, in Lyng v. Northwest Indian Cemetery Protective Association (U.S. 1987 at 445), the majority emphasized approvingly that the Forest Service had established in their management plan half-mile "protective zones" around "all the religious sites"—an argument that implicitly omits consideration of the larger space as a sacred landscape.

61. Religious Freedom Restoration Act, Pub. L. No. 013-141, 42 USC 2000bb (1993).

62. Ibid., $\S 3$ a. RFRA entails, in essence, a reaffirmation and restoration of the Sherbert test in US religious freedom law, which arose from the 1963 Sherbert v. Verner case, 378 U.S. 398 (1963). The test became eroded in subsequent case law, however; for example, Employment Division v. Smith, 494 U.S. 782 (1990) weakened the requirement for the government to establish a "compelling interest" and, in the language of the RFRA, to demonstrate that actions had been taken in the "least-restrictive manner." Indeed, the weakening of free-exercise protections in these landmark cases was a central factor leading to RFRA's passage. See Ann M. Hooker, "American Indian Sacred Sites on Federal Public Lands: Resolving Conflicts between Religious Use and Multiple Use at El Mapais National Monument," American Indian Law Review 19, no. 1 (1994): 154; Rebecca A. Tsosie, "Challenges to Sacred Site Protection," Denver University Law Review 83, no. 4 (2006): 963-980, 969; Wiseman, "Why the Religious Freedom Restoration Act Cannot Protect Sacred Sites," 140-41; Yablon, "Property Rights and Sacred Sites," 1641.

63. Hardgrave, "Hell on Earth"; Thomas F. King, "Commentary: What Burdens Religion? Musings on Two Recent Cases Interpreting the Religious Freedom Restoration Act," Great Plains Natural Resources Journal 13 (2010): 1-11.

64. Walter R. Echo-Hawk, In the Court of the Conqueror: The 10 Worst Indian Law Cases Ever Decided (Golden, CO: Fulcrum Publishing, 2010).

65. Navajo Nation v. United States Forest Service, 535 F.3d 1058 (9th Cir. 2008).

66. Ibid., 1063.

67. Ibid., 1070 .

68. One might suggest, as did one reviewer of this article, that such an assertion reflects a dominant settler discourse in which sacred ritual is considered to be primarily about symbolic expression, rather than experience and effecting change in the actual world. If ritual is regarded as being purely internal and not physically "real," desecration is consequently also "unreal." 
69. Schultz, “Decolonizing Political Ecology," 110.

70. Navajo Nation v. United States Forest Service, 1063.

71. Dunstan, "Toxic Desecration."

72. Robert S. McPherson, "Powers, Prayers, and Protection: Comb Ridge as a Case Study in Navajo Thought," American Indian Culture and Research Journal 34, no. 1 (2010): 19, https://doi. org/10.17953/aicr.34.1.4036724589013702.

73. Tom Marcinko, "Man-made Snow from Reclaimed Sewage Water at Heart of Hopi, Ski Resort Fight," February 9, 2014, http://america.aljazeera.com/articles/2014/2/9/manmade-snowfromreclaimedsewageatheartofhopiarizresortfight.html.

74. Catherine A. Propper, "The Study of Endocrine-Disrupting Compounds: Past Approaches and New Directions," Integrative and Comparative Biology 45, no. 1 (2005): 194-200, https://doi. org/10.1093/icb/45.1.194; Amy Pruden, Maureen O’Brien, Mark Mazzochette, and Nicole Fahrenfeld, "Antibiotic Resistance Gene Testing of Recycled Water Samples. Summary Report to Dr. Robin Silver," https://www.scribd.com/document/106095265/Arg.

75. Noel Lynn Smith, "Hopi Continues to Fight Snowbowl," Navajo Times, November 21, 2012, http://navajotimes.com/news/2012/1112/112112sno.php.

76. Interview with Diné individual, June, 2009. All personal names of interviewees are pseudonyms to protect confidentiality.

77. Leland C. Wyman, Soutbwest Indian Drypainting (Santa Fe: School of American Research and Albuquerque: University of New Mexico Press, 1983), 20.

78. Interview with Diné individual, August, 2013. These specific details are widely known in the public literature; this article discloses no new information about Diné ceremonies. See, for example, Michaelson, "Dirt in the Courtroom," 43.

79. Interview with Diné individual, July, 2009; interview with Diné individual, August, 2013. See also United States Department of Agriculture, Forest Service, Southwestern Region, "Final Environmental Impact Statement for Arizona Snowbowl Facilities Improvements," vol. 1: Coconino National Forest, Coconino County (February, 2005), 3-17, https://www.fs.usda.gov/Internet/FSE_ DOCUMENTS/stelprd3831728.pdf.

80. Clyde Kluckhohn and Dorothea Leighton, The Navabo (Cambridge: Harvard University Press, 1970 [1946]), 202.

81. Interview with Diné individual, August, 2013.

82. Maureen T. Schwarz, Blood and Voice: Navajo Women Ceremonial Practitioners (Tucson: University of Arizona Press, 2003).

83. Interview with Diné individual, August, 2013.

84. Instances in the snowmaking case have parallels to additional Diné landscapes associated with healing or other ceremonial activities. Among other instances of diminishment of power and socioecological disruption across landscapes, Klara B. Kelley and Harris Francies discuss a quarry on Volcanic Woodruff Butt in Navajo Sacred Places (Indianapolis: Indiana University Press, 1994), 178-79; and Stephen C. Jett speaks of communication towers on Navajo Mountain and electrical towers on El Huerfano Mesa, as well as coal strip-mining of Black Mesa in "Navajo Sacred Places: Management and Interpretation of Mythic History," The Public Historian 17, no. 2 (1995), 42-43, https://doi.org/10.2307/3378125.

85. United States Department of Agriculture, "Final Environmental Impact Statement for Arizona Snowbowl Facilities Improvements," 3-50.

86. Echo-Hawk, In the Courts of the Conqueror.

87. Ulrich Demmer and Agata Hummel, "Degrowth, Anthropology, and Activist Research: The Ontological Politics of Science," Journal of Political Ecology 24 (2017): 612, http://jpe.library.arizona. edu/volume_24/Demmer.pdf. 
88. Such understandings are diverse. One Diné colleague of mine explained to me, rather than a distinct Being, a more correct understanding would be that the mountain is simply alive, as indeed the entire earth is.

89. Navajo Nation v. United States Forest Service, 535 F.3d at 1065 (9th Cir. 2008). It might be added that in some aspects, ADEQ-based claims for the water's safety is antithetical to the findings of other laboratory scientists. See Propper, "The Study of Endocrine-Disrupting Compounds," 194-200; Pruden, et al., "Antibiotic Resistance Gene Testing," 5.

90. Quoted in Joey Postiglione, "City Passes Resolution Against DAPL Project," The Lumberjack, March 22, 2017, http://www.jackcentral.org/news/city-passes-resolution-against-dapl-project/ article_444ada64-0f53-11e7-bb48-2b7fa463b5a4.html.

91. Ibid.

92. For a discussion of two landmark instances of such conflict, the construction of the Tellico dam and the flooding of the area near Rainbow Bridge, see Stambor, "Manifest Destiny and American Indian Religious Freedom," 59-89.

93. Hardgrave, "Hell on Earth," 13. 